\title{
ANALISIS PENGAKUAN DAN PENGUKURAN PENDAPATAN BERDASARKAN PSAK NO. 23 (REVISI 2015) \\ PT GUNUNG SAKTI MAKMUR 2012-2016
}

\author{
Ririn Setianingsih \\ Alumni Program Studi Akuntansi S1 \\ Sekolah Tinggi Ilmu Ekonomi Bisnis Indonesia, Jakarta \\ dan \\ Rudy \\ Dosen STIE Bisnis Indonesia, Jakarta
}

\begin{abstract}
The research method used is accrual basis method and cash basis method. The results show that the method of recognizing and measuring revenue based on PSAKNo. 23 (Revised 2015) at PT Gunung Sakti Makmur is only applied after the company's internal audit is conducted by comparing two periods of financial statements. After an internal audit, the recognition of PT Gunung Sakti Makmur's revenue is applied using the accrual basis method where economic and event transactions are recognized, recorded and presented in the financial statements at the time of the transaction without regard to cash received or paid. The recognition of PT Gunung Sakti Makmur's revenues applied has been referred to the PSAK No. 23 (Revised 2015) is seen from the sale of services recorded as such income can be estimated with certainty and most likely to be realized. The measurement of income is based on the amount of money received from the customer minus the costs.
\end{abstract}

Keywords: Revenue Recognition and Measurement, PSAKNo. 23 (Revised 2015)

\begin{abstract}
Abstrak: Metode penelitian yang digunakan adalah metode accrual basis dan cash basis.Hasil penelitian menunjukkan bahwa metode pengakuan dan pengukuran pendapatan berdasarkan PSAKNo. 23 (Revisi 2015) pada PT Gunung Sakti Makmur baru diterapkan setelah dilakukan audit intern perusahaan yakni dengan membandingkan dua periode laporan keuangan. Setelah dilakukan audit intern, pengakuan pendapatan PT Gunung Sakti Makmur yang diterapkan menggunakan metode accrual basis dimana transaksi ekonomi dan peristiwadiakui, dicatat, dan disajikan dalam laporan keuangan pada saat terjadinya transaksi tersebut tanpa memperhatikan waktu kas diterima atau dibayar. Pengakuan pendapatan PT Gunung Sakti Makmur yang diterapkan telah mengacu pada PSAK No. 23 (Revisi 2015) terlihat dari penjualan jasa yang dicatat sebagai pendapatan tersebut dapat diestimasi dengan pasti dan besar kemungkinannya dapat direalisasikan. Pengukuran pendapatan dilakukan berdasarkan jumlah uang yang diterima dari customer dikurangi biaya-biaya. Kata Kunci: Pengakuan dan Pengukuran Pendapatan, PSAK No. 23 (Revisi 2015)
\end{abstract}




\section{Pendahuluan}

Perusahaan stockpile adalah perusahaan yang kegiatannya menampung/menimbun sementara batubara untuk kemudian menyalurkannya pada pelanggan siap pakai, khususnya pada industri berskala besar yakni digunakan sebagai bahan bakar dalam proses produksi industri seperti industri kertas dan industri pengolahan minyak goreng. Selain untuk menampung sementara batubara, perusahaan stockpile juga berfungsi sebagai safety stock terhadap gangguan yang bersifat jangka pendek atau jangka panjang. Penimbunan batubara merupakan salah satu tahapan penting dari kegiatan penanganan batubara. Apabila sistem penimbunan kurang memadai maka dapat mengganggu kegiatan pembongkaran timbunan batubara di tempat penimbunan, terutama bagi batubara yang mudah terbakar dengan sendirinya. Sehingga dengan adanya upaya perbaikan manajemen timbunan, upaya menghindari gejala terbakarnya batubara karena paparan panas yang berlebih (swabakar) dan upaya menghindari dan mengatasi timbulnya genangan air dapat dicegah sekecil mungkin.

Dalam proses blending batubara harus tercampur secara merata sedangkan mixing merupakan salah satu tipe batubara yang tercampur masih dapat dilokasikan dalam kuantitas kecil dari hasil campuran material dari dua atau lebih tipe batubara. Dari sini industri yang terkait mengupayakan mendapatkan pasokan batubara dari perusahaan yang berkompeten dalam bidang ini. Perusahaan batubara yang pada awalnya banyak terdapat pada area pertambangan batubara inipun mulai melirik pasar industri manufaktur yang kian berkembang pada daerah Ibu Kota. Sejalan dengan berkembangnya waktu, perusahaan batubara kini bukan hanya berada pada daerah penambangan batubara saja. Namun juga merambah ke daerah Ibu Kota. Hal ini ditunjukkan dengan mulai banyaknya perusahaan stockpile yang menjadi rekanan dari perusahaan batubara.

Alasan penulis memilih penelitian ini adalah terkait pada saat pengakuan pendapatan (revenue recognition) dan pengukuran pendapatan (revenue measurement). Pengakuan pendapatan merupakan saat dimana sebuah transaksi harus diakui sebagai pendapatan perusahaan. Sedangkan pengukuran pendapatan adalah berapa besar jumlah pendapatan yang seharusnya diakui dari setiap transaksi yang terjadi pada suatu periode tertentu. Maka pengakuan dan pengukuran pendapatan harus dilakukan dengan akurat agar perusahaan mampu menyajikan laporan keuangan secara wajar. Apabila pendapatan yang diakui tidak sama dengan yang seharusnya maka ini berarti pendapatan yang diukur bisa salah (baik itu terlalu besar atau terlalu kecil). Hal ini dapat mengakibatkan informasi yang disajikan dalam laporan laba rugi tidak tepat dan dapat menyebabkan kesalahan dalam pengambilan keputusan oleh pihak manajemen perusahaan. Di dalam PSAK nomor 23 diuraikan dan dijelaskan tentang pengakuan dan pengukuran pendapatan yang dapat digunakan bagi perusahaan-perusahaan. Oleh karena itu, pengukuran pendapatan dikatakan tepat dan akurat apabila mengacu pada PSAK No. 23 (Revisi 2015). Berdasarkan hal tersebut, maka penulis merasa tertarik untuk membahas penerapan akuntansi atas pengakuan dan pengukuran pendapatan pada perusahaan dagang. Untuk itu penulis melakukan penelitian dan membuat skripsi yang berjudul "Analisis Pengakuan dan Pengukuran Pendapatan Berdasarkan PSAK No. 23 (Revisi 2015) PT Gunung Sakti Makmur 2012-2016.“

\section{Landasan Teori}

\subsection{Akuntansi}

Menurut Accounting Principles Board dalam Hery (2016:1), "Akuntansi adalah suatu kegiatan jasa. Fungsinya adalah untuk menyediakan informasi kuantitatif, terutama yang bersifat keuangan, tentang entitas ekonomik yang dimaksudkan agar berguna dalam pengambilan keputusan ekonomik dalam mengambil pilihan-pilihan beralasan di antara berbagai tindakan alternatif. Akuntansi meliputi beberapa cabang, misalnya akuntansi keuangan, akuntansi manajemen dan akuntansi pemerintah." 


\subsubsection{Laporan Keuangan}

Menurut PSAK No. 1 (Revisi 2015) oleh Ikatan Akuntan Indonesia (2015:3), "Laporan keuangan adalah suatu penyajian terstruktur dari posisi keuangan dan kinerja keuangan suatu entitas. Tujuan laporan keuangan adalah untuk memberikan informasi mengenai posisi keuangan, kinerja keuangan, dan arus kas entitas yang bermanfaat bagi sebagian besar pengguna laporan keuangan dalam pembuatan keputusan ekonomik. Laporan keuangan juga menunjukkan hasil pertanggungjawaban manajemen atas penggunaan sumber daya yang dipercaya kepada mereka." Menurut Kieso, dkk (2011:5), "Laporan keuangan adalah sarana utama dimana sebuah perusahaan mengkomunikasikan informasi keuangan kepada orang luar."

\subsubsection{Pendapatan}

Laporan laba rugi adalah laporan keuangan yang secara sistematik menyajikan hasil usaha perusahaan dalam rentang waktu tertentu (Sodikin dan Riyono, 2016:36). Pendapatan merupakan unsur yang paling utama dalam menentukan tingkat laba yang diperoleh suatu perusahaan dalam satu periode akuntansi yang diakui sesuai dengan prinsip-prinsip yang berlaku umum.

\subsubsection{Klasifikasi Pendapatan}

Terdapat dua konsep yang sangat erat hubungannya dengan masalah pendapatan yaitu:

1. Proses pembentukan pendapatan (earning process)

2. Proses realisasi pendapatan (realization process)

Proses realisasi pendapatan ditandai oleh dua kejadian berikut ini:

a. Kepastian perubahan produk menjadi potensi jasa yang lain melalui proses penjualan yang sah.

b. Pengesahan atau validasi transaksi penjualan tersebut dengan aktiva lancar.

Pendapatan dapat diklasifikasikan berdasarkan sumbernya, yang digunakan untuk menghasilkan informasi yang digunakan perusahaan untuk menyiapkan dan mengontrol anggaran, mengontrol pengumpulan pendapatan, menyiapkan laporan keuangan. Menurut sumbernya, pendapatan dibedakan menjadi dua jenis yaitu pendapatan yang berasal dari kegiatan utama perusahaan (pendapatan operasional), dan pendapatan yang berasal dari luar kegiatan perusahaan (pendapatan non operasional).

\subsubsection{Karakteristik Pendapatan}

Ada beberapa karakteristik tertentu dari pendapatan yang menentukan atau membatasi bahwa sejumlah rupiah yang masuk ke perusahaan merupakan pendapatan yang berasal dari operasi perusahaan. Karakteristik tersebut antara lain berdasarkan sumber pendapatan, produk dan kegiatan utama perusahaan dan jumlah rupiah pendapatan serta proses penandingan.

1. Sumber Pendapatan

2. Produk dan Kegiatan Utama Perusahaan

3. Jumlah Rupiah Pendapatan dan Proses Penandingan

\subsubsection{Pengakuan dan Pengukuran Pendapatan Berdasarkan PSAK No. 23}

Dalam Pernyataan Standar Akuntansi Keuangan (PSAK) Nomor 23 paragraf ke 22 (Revisi 2015) menyatakan bahwa pendapatan diakui bila besar kemungkinan manfaat ekonomi masa depan akan mengalir ke perusahaan. Pernyataan Standar Akuntansi Keuangan No. 23 paragraf ke 24 (Revisi 2015) menyatakan bahwa tingkat penyelesaian transaksi dapat ditentukan dengan berbagai metode. Bergantung pada sifat transaksi, metode tersebut dapat mencakup: 
1. Survei pekerjaan yang telah dilaksanakan.

2. Jasa yang dilakukan hingga tanggal tertentu sebagai persentase dari total jasa yang dilakukan, atau

3. Proporsi biaya yang timbul hingga tanggal tertentu dibagi estimasi total biaya transaksi tersebut. Hanya biaya yang mencerminkan jasa yang dilaksanakan hingga tanggal tertentu yang dimasukkan dalam biaya yang terjadi hingga tanggal tersebut. Hanya biaya yang mencerminkan jasa yang dilakukan atau akan dilakukan dimasukkan ke dalam estimasi total biaya transaksi tersebut.

\subsubsection{Pengakuan Pendapatan (Revenue Recognition)}

Harahap (2011:96) menyatakan bahwa pengakuan adalah proses pembentukan suatu pos yang memenuhi definisi unsur kriteria pengakuan yang sesuai dengan Standar Akuntansi dalam Laporan Neraca dan Laba Rugi:

1. Ada kemungkinan manfaat ekonomi yang berkaitan dengan pos tersebut akan mengalir dari atau kedalam perusahaan.

2. Pos tersebut mempunyai nilai atau biaya yang dapat diukur dengan andal.

Pawan (2013:351) menjelaskan bahwa selama ini ada dua dasar pengakuan dari pendapatan pendapatan, yaitu:

1. Accrual Basis

Dasar aktual ini mengakui pendapatannya pada saat periode terjadinya transaksi pendapatan. Dengan dasar ini, pengaruh transaksi dan peristiwa lain diakui pada saat kejadian walaupun kas belum diterima.

2. Cash Basis

Dasar tunai ini mengakui apabila pendapatan yang hanya diperhitungkan berdasarkan penerimaan dan pengeluaran kas. Dan penjualan barang atau jasa hanya dapat diperhitungkan pada saat tagihan langganan diterima.

Tabel 2.1

Metode, Waktu Pengakuan Pendapatan dan Perlakuan Biaya

\begin{tabular}{|c|c|c|c|}
\hline No. & Metode & $\begin{array}{l}\text { Waktu Pengakuan } \\
\text { Pendapatan }\end{array}$ & $\begin{array}{c}\text { Perlakuan Biaya Produk } \\
\text { atau Biaya Langsung dalam } \\
\text { Kontrak Jasa }\end{array}$ \\
\hline 1. & Akrual Penuh & Pada titik penjualan & $\begin{array}{l}\text { Dibebankan terhadap } \\
\text { pendapatan pada waktu } \\
\text { penjualan atau pelaksanaan } \\
\text { kas. }\end{array}$ \\
\hline 2. & $\begin{array}{l}\text { Penjualan } \\
\text { Cicilan }\end{array}$ & $\begin{array}{l}\text { Pada saat pembayaran kas. } \\
\text { Biasanya sebagian dari } \\
\text { pembayaran kas diakui } \\
\text { sebagian laba. }\end{array}$ & $\begin{array}{l}\text { Ditangguhkan guna dikaitkan } \\
\text { dengan sebagian dari setiap } \\
\text { pembayaran kas. Biasanya } \\
\text { dilakukan dengan } \\
\text { menangguhkan laba yang } \\
\text { diestimasi. }\end{array}$ \\
\hline 3. & $\begin{array}{l}\text { Pemulihan } \\
\text { Biaya }\end{array}$ & $\begin{array}{l}\text { Pada saat pembayaran kas, } \\
\text { tetapi hanya dipulihkan. }\end{array}$ & $\begin{array}{l}\text { Ditangguhkan guna dikaitkan } \\
\text { dengan total kas yang diterima. }\end{array}$ \\
\hline 4. & Kas & Pada saat pembayaran. & $\begin{array}{l}\text { Dibukukan sebagai beban pada } \\
\text { saat terjadinya. }\end{array}$ \\
\hline
\end{tabular}

Sumber: Stice (2009:526). 


\subsubsection{Pengukuran Pendapatan (Revenue Measurement)}

Cara terbaik untuk mengukur pendapatan adalah dengan menggunakan nilai tukar dari barang atau jasa. Harahap (2011:96), "Pengukuran adalah proses penetapan jumlah uang untuk mengakui dan memasukkan setiap unsur laporan keuangan dalam neraca atau laporan laba rugi." Ada lima dasar pengukuran pendapatan menurut Statement of Financial Accounting Concepts (SFAC) No. 5 yaitu:

1. Biaya Historis (Historical Cost)

2. Biaya Penggantian Terkini (Current Replacement Cost)

3. Nilai Pasar Terkini (Current Market Value)

4. Nilai Bersih yang Dapat Direalisasi (Net Realisable Value)

5. Nilai Sekarang yang Didiskontokan (Current Discounted Value)

\subsection{Kerangka Pikir}

Gambar 2.1

Kerangka pikir

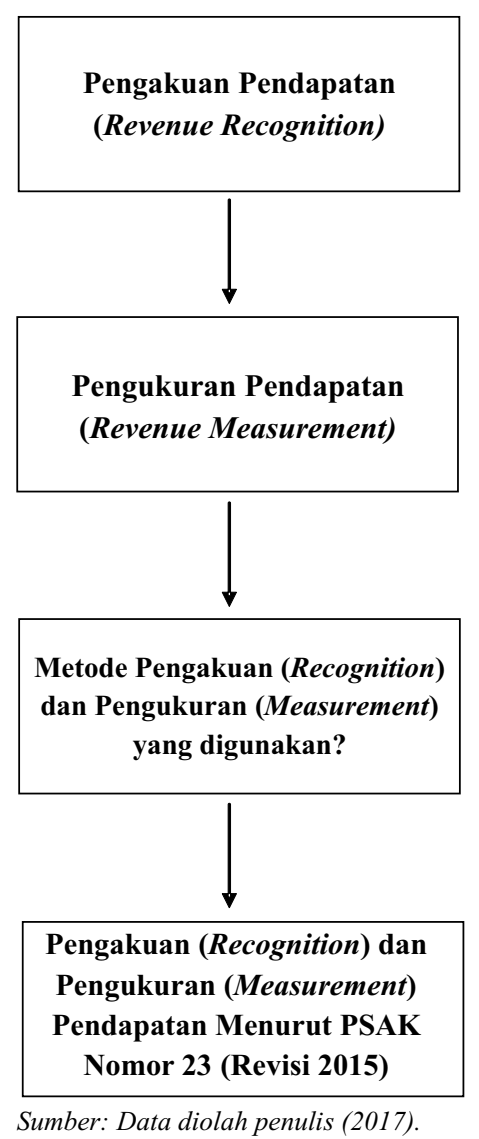

\section{Metodologi Penelitian}

\subsection{Metode penelitian}

Sugiyono (2010:13) mendefinisikan objek penelitian adalah sasaran ilmiah untuk mendapatkan data dengan tujuan dan kegunaan tertentu tentang sesuatu hal objektive, valid dan reliable tentang suatu hal (variabel tertentu). Strategi yang digunakan dalam penelitian ini adalah strategi penelitian deskriptif. Pendekatan deskriptif yaitu metode yang menerapkan atau menggambarkan secara 
sistematis, faktual dan akurat dengan cara mengungkapkan keadaan yang sebenarnya terjadi dalam perusahaan atau objek penelitian dengan mengumpulkan data-data relevan yang tersedia, kemudian dianalisis dan dibandingkan dengan teori-teori yang ada, sehingga dapat memberikan gambaran yang jelas atas objek penelitian. Metode yang digunakan dalam penelitian ini adalah metode observasi langsung. Dengan metode observasi langsung penulis yakin bahwa data yang diperoleh akan lebih akurat, dan mengetahui lebih rinci mengenai perlakuan akutansi pengakuan pendapatan pada PT Gunung Sakti Makmur penulis dapat secara langsung mengamati kejadian atau fakta yang terjadi di tempat dilakukannya penelitian, yaitu pada PT Gunung Sakti Makmur.

\subsection{Jenis Data}

Sugiyono (2010:15) menjelaskan bahwa data kuantitatif adalah jenis data yang dapat diukur atau dihitung secara langsung, yang berupa informasi atau penjelasan yang dinyatakan dengan bilangan atau berbentuk angka. Dalam hal ini data kuantitatif yang diperlukan adalah: jumlah guru, siswa dan karyawan, jumlah sarana dan prasarana, dan hasil angket.

\subsection{Sumber Data}

Data dalam penelitian ini adalah data primer. Data primer yang dimaksudkan adalah berupa jawaban/hasil wawancara dan data sekunder berupa dokumen penjualan dan surat-surat penjualan. Data ini berguna untuk memperkuat uraian teoritis penelitian dalam penulisan skripsi.

\subsection{Teknik Analisis Data}

Dalam penyusunan skripsi ini penulis menggunakan:

1. Metode Accrual Basis

Suatu metode dimana dasar aktual ini mengakui pendapatannya pada saat periode terjadinya transaksi pendapatan. Dengan dasar ini, pengaruh transaksi dan peristiwa lain diakui pada saat kejadian walaupun kas belum diterima.

2. Metode Cash Basis

Suatu metode analisa yang dilakukan dengan dasar tunai ini mengakui apabila pendapatan yang hanya diperhitungkan berdasarkan penerimaan dan pengeluaran kas. Dan penjualan barang atau jasa hanya dapat diperhitungkan pada saat tagihan langganan diterima.

\section{Hasil Temuan dan Pembahasan}

\subsection{Hasil Temuan}

Coal stockpile adalah layanan jasa sewa tempat penyimpanan/penimbunan sementara batubara sebelum sampai pada customer. Perhitungan dari pendapatan coal stockpile ini adalah jumlah tonase masuk dikalikan dengan harga yang telah disepakati oleh PT Gunung Sakti Makmur dan customer. Untuk proses penyimpanan/penimbunan digunakan jangka waktunya tidak lama, karena akan berakibat pada penurunan kualitas batubara. Proses penurunan kualitas biasanya lebih dipengaruhi oleh proses oksidasi dan alam. Hal ini adalah salah satu upaya PT Gunung Sakti Makmur dalam memilih rekanan usaha yang saling menguntungkan. Hal ini sesuai dengan komitmen PT Gunung Sakti Makmur untuk memberikan pelayanan terbaik untuk customer.

\subsubsection{Pendapatan dari Coal Screening}

Coal Screening adalah layanan jasa berupa proses pengelompokan batubara sesuai dengan ukuran yang seragam. Adapun perhitungan pendapatan dari coal screening ini adalah jumlah tonase batubara yang proses screening dikalikan dengan tarif yang disepakati. Setelah dilakukan coal screening akan terpisah batubara sesuai ukuran yang dibutuhkan dan siap untuk didistribusikan pada customer. Untuk perhitungan pendapatan dari coal blending juga sama dengan perhitungan dari coal 
stockpile dan coal screening, yakni jumlah tonase batubara yang diproses blending dikalikan dengan tarif yang telah disepakati.

\subsubsection{Pendapatan Bunga}

Selain dari aktivitas perusahaan (coal stockpile, coal screening dan coal blending), PT Gunung Sakti Makmur mendapat pemasukan pendapatan dari pendapatan bunga bank yang diterima setiap bulannya.

\subsection{Analisis Data}

\subsubsection{Pengakuan Pendapatan}

Pengakuan pendapatan menurut prinsip berlaku umum pada PT Gunung Sakti Makmur menjelaskan dalam hal kebijaksanaan mengenai pengakuan pendapatan sebagai hasil dari penjualan jasa coal stockpile, coal screening dan coal blending lebih mengacu pada konsep accrual basis, yakni pendapatan diakui pada saat setelah terjadinya pendapatan dan biaya pada periode bersamaan. Dengan kata lain pendapatan harus sejalan dengan biaya pada periode tersebut. Saat itu PT Gunung Sakti Makmur akan mengeluarkan nota debet kepada pemakai jasa untuk melakukan pembayaran. Pembayaran bisa dilakukan secara transfer ke rekening PT Gunung Sakti Makmur yang tertera pada tagihan invoice yang telah dikirim pada customer. Laporan penjualan jasa (coal stockpile, coal screening dan coal blending) PT Gunung Sakti Makmur per bulan selama tahun 2012-2016 adalah sebagai berikut:

Tabel 4.1

Laporan Penjualan Jasa PT Gunung Sakti Makmur Tahun 2012-2016

\begin{tabular}{|l|r|r|r|r|r|}
\hline Bulan & \multicolumn{1}{|c|}{$\mathbf{2 0 1 2}$} & $\mathbf{2 0 1 3}$ & $\mathbf{2 0 1 4}$ & \multicolumn{1}{c|}{$\mathbf{2 0 1 5}$} & \multicolumn{1}{c|}{$\mathbf{2 0 1 6}$} \\
\hline JAN & 65.009 .578 & 310.345 .460 & 240.401 .250 & 337.570 .442 & 285.669 .710 \\
\hline FEB & 58.385 .012 & 275.665 .800 & 285.035 .560 & 430.165 .032 & 450.698 .520 \\
\hline MAR & 77.004 .582 & 325.998 .025 & 356.879 .005 & 711.306 .706 & 689.775 .022 \\
\hline APR & 46.378 .040 & 398.560 .255 & 486.302 .774 & 692.930 .821 & 720.336 .785 \\
\hline MEI & 30.664 .096 & 495.885 .664 & 601.552 .845 & 745.498 .252 & 880.026 .055 \\
\hline JUN & 67.764 .890 & 500.125 .846 & 701.998 .565 & 784.283 .840 & 820.368 .750 \\
\hline JUL & 112.956 .300 & 611.548 .675 & 801.558 .996 & 844.038 .042 & 985.223 .550 \\
\hline AGS & 98.456 .320 & 665.843 .002 & 822.004 .875 & 835.442 .503 & 1.005 .872 .056 \\
\hline SEP & 88.457 .040 & 700.765 .890 & 888.336 .580 & 952.315 .195 & 1.358 .026 .748 \\
\hline OKT & 96.530 .084 & 715.685 .430 & 845.203 .428 & 946.566 .698 & 1.895 .023 .640 \\
\hline NOV & 128.007 .605 & 755.846 .204 & 815.879 .420 & 904.367 .469 & 1.500 .855 .470 \\
\hline DES & 132.095 .763 & 700.854 .756 & 784.532 .844 & 883.217 .603 & 1.702 .358 .740 \\
\hline & 1.001 .709 .310 & 6.457 .125 .007 & 7.629 .686 .142 & 9.067 .702 .603 & 12.294 .235 .046 \\
\hline
\end{tabular}

Sumber: PT Gunung Sakti Makmur (2012-2016).

Dari tabel 4.1 dilihat penjualan jasa PT Gunung Sakti Makmur meningkat setiap tahunnya. Namun terdapat peningkatan yang signifikan terjadi pada tahun 2012 ke tahun 2013 yaitu sebesar Rp 5.455.415.697. Hal ini membuat perusahaan mengadakan penelitian lebih lanjut untuk pengungkapan pengukuran pendapatan untuk mengetahui apakah penjualan jasa yang telah dilakukan PT Gunung Sakti Makmur sudah sesuai dengan ketentuan akuntansi yang benar.

\subsubsection{Pengukuran Pendapatan}

Pendapatan diukur dengan jumlah uang ekuivalen yang dapat diterima dengan harga yang disetujui oleh kedua belah pihak dan dipertukarkan dalam bentuk independen. Jumlah uang yang ekuivalen ini dapat diterapkan untuk pengukuran dan diperoleh dari transaksi non kas. Dengan dasar ini maka 
besarnya pendapatan adalah sama dengan harga tunai dalam penjualan jasa dan aktiva lainnya. Jumlah pendapatan yang timbul dari suatu transaksi, biasanya ditentukan oleh persetujuan antara perusahaan dan pembeli atau pemakai aktiva tersebut. Jumlah tersebut diukur dengan nilai wajar imbalan yang diterima perusahaan dikurangi diskon yang diperbolehkan oleh perusahaan. Berikut adalah contoh pengukuran pendapatan PT Gunung Sakti Makmur yang diambil pada data penjualan jasa (coal stockpile, coal screening dan coal blending) tahun 2015.

Tabel 4.2

Pendapatan Penjualan Jasa Coal Stockpile Tahun 2015

\begin{tabular}{|l|c|c|c|}
\hline \multicolumn{1}{|c|}{ Bulan } & Tarif & Tonase & Jumlah \\
\hline Januari & 22 & 11.395 .910 & 250.710 .020 \\
\hline Februari & 22 & 15.255 .810 & 335.627 .820 \\
\hline Maret & 22 & 26.999 .830 & 593.996 .260 \\
\hline April & 22 & 24.758 .334 & 544.683 .337 \\
\hline Mei & 22 & 26.773 .069 & 589.007 .524 \\
\hline Juni & 22 & 29.108 .500 & 640.387 .001 \\
\hline Juli & 22 & 31.866 .099 & 701.054 .167 \\
\hline Agustus & 22 & 31.313 .060 & 688.887 .314 \\
\hline September & 22 & 36.389 .646 & 800.572 .203 \\
\hline Oktober & 22 & 35.853 .491 & 788.776 .805 \\
\hline Nopember & 22 & 34.404 .698 & 756.903 .347 \\
\hline Desember & 22 & 32.759 .593 & 720.711 .036 \\
\hline & & & 7.411 .316 .834 \\
\hline
\end{tabular}

Sumber: PT Gunung Sakti Makmur (2016)

Dari tabel 4.2 di atas dapat dilihat pengukuran pendapatan pada PT Gunung Sakti Makmur dapat diukur dengan andal dengan menggunakan satuan mata uang rupiah. Adapun perhitungan dari pendapatan penjualaan jasa coal stockpile ini sendiri yaitu tarif yang diberlakukan/disepakati dikalikan dengan jumlah tonase batubara. Hasil dari perkalian inilah yang kemudian disebut pendapatan coal stockpile.

Tabel 4.3

Pendapatan Penjualan Jasa Coal Sreening Tahun 2015

\begin{tabular}{|l|l|l|r|}
\hline \multicolumn{1}{|c|}{ Bulan } & Tarif & Tonase & \multicolumn{1}{c|}{ Jumlah } \\
\hline Januari & 19,8 & 4.024 .450 & 79.684 .110 \\
\hline Februari & 19,8 & 4.369 .580 & 86.517 .684 \\
\hline Maret & 19,8 & 5.737 .080 & 113.594 .184 \\
\hline April & 19,8 & 7.287 .910 & 144.300 .618 \\
\hline Mei & 19,8 & 7.687 .155 & 152.205 .666 \\
\hline Juni & 19,8 & 7.098 .398 & 140.548 .279 \\
\hline Juli & 19,8 & 6.997 .874 & 138.557 .907 \\
\hline Agustus & 19,8 & 7.164 .389 & 141.854 .902 \\
\hline September & 19,8 & 7.400 .117 & 146.522 .308 \\
\hline Oktober & 19,8 & 7.592 .914 & 150.339 .704 \\
\hline Nopember & 19,8 & 7.203 .543 & 142.630 .142 \\
\hline Desember & 19,8 & 7.929 .479 & 157.003 .694 \\
\hline \multicolumn{2}{|c|}{} & & 1.593 .759 .198 \\
\hline
\end{tabular}

Sumber: PT Gunung Sakti Makmur (2016). 
Tidak berbeda dengan perhitungan penjualan jasa coal stockpile, penjualan jasa coal screening juga masih memakai rumus yang sama yaitu perkalian antara tarif yang diberlakukan/disepakati dengan tonase batubara. Penjualan jasa coal screening ini merupakan penjualan jasa tertinggi ke dua setelah penjualan coal stockpile pada PT Gunung Sakti Makmur.

Tabel 4.4

Pendapatan Penjualan Jasa Coal Blending Tahun 2015

\begin{tabular}{|l|r|r|r|}
\hline \multicolumn{1}{|c|}{ Bulan } & Tarif & \multicolumn{1}{c|}{ Tonase } & \multicolumn{1}{c|}{ Jumlah } \\
\hline Januari & 6,6 & 1.087 .320 & 7.176 .312 \\
\hline Februari & 6,6 & 1.215 .080 & 8.019 .528 \\
\hline Maret & 6,6 & 563.070 & 3.716 .262 \\
\hline April & 6,6 & 598.010 & 3.946 .866 \\
\hline Mei & 6,6 & 649.252 & 4.285 .062 \\
\hline Juni & 6,6 & 507.358 & 3.348 .560 \\
\hline Juli & 6,6 & 670.601 & 4.425 .968 \\
\hline Agustus & 6,6 & 712.165 & 4.700 .287 \\
\hline September & 6,6 & 791.013 & 5.220 .684 \\
\hline Oktober & 6,6 & 1.128 .817 & 7.450 .189 \\
\hline Nopember & 6,6 & 732.421 & 4.833 .980 \\
\hline Desember & 6,6 & 833.769 & 5.502 .873 \\
\hline & & & 62.626 .571 \\
\hline
\end{tabular}

Sumber: PT Gunung Sakti Makmur (2016) .

\subsection{Pembahasan}

Hal ini bisa di lihat dari perbandingan penjualan jasa (coal stockpile, coal screening dan coal blending) pada PT Gunung Sakti Makmur tahun 2012-2016.

Tabel 4.5

Selisih Penjualan Jasa (coal stockpile, coal screening dan coal blending)

Tahun 2012-2016

\begin{tabular}{|l|r|r|r|r|r|}
\hline \multicolumn{1}{|c|}{ Bulan } & \multicolumn{1}{c|}{$\mathbf{2 0 1 2}$} & $\mathbf{2 0 1 3}$ & $\mathbf{2 0 1 4}$ & \multicolumn{1}{c|}{$\mathbf{2 0 1 5}$} & \multicolumn{1}{c|}{$\mathbf{2 0 1 6}$} \\
\hline JAN & 65.009 .578 & 310.345 .460 & 240.401 .250 & 337.570 .442 & 285.669 .710 \\
\hline FEB & 58.385 .012 & 275.665 .800 & 285.035 .560 & 430.165 .032 & 450.698 .520 \\
\hline MAR & 77.004 .582 & 325.998 .025 & 356.879 .005 & 711.306 .706 & 689.775 .022 \\
\hline APR & 46.378 .040 & 398.560 .255 & 486.302 .774 & 692.930 .821 & 720.336 .785 \\
\hline MEI & 30.664 .096 & 495.885 .664 & 601.552 .845 & 745.498 .252 & 880.026 .055 \\
\hline JUN & 67.764 .890 & 500.125 .846 & 701.998 .565 & 784.283 .840 & 820.368 .750 \\
\hline JUL & 112.956 .300 & 611.548 .675 & 801.558 .996 & 844.038 .042 & 985.223 .550 \\
\hline AGS & 98.456 .320 & 665.843 .002 & 822.004 .875 & 835.442 .503 & 1.005 .872 .056 \\
\hline SEP & 88.457 .040 & 700.765 .890 & 888.336 .580 & 952.315 .195 & 1.358 .026 .748 \\
\hline OKT & 96.530 .084 & 715.685 .430 & 845.203 .428 & 946.566 .698 & 1.895 .023 .640 \\
\hline NOV & 128.007 .605 & 755.846 .204 & 815.879 .420 & 904.367 .469 & 1.500 .855 .470 \\
\hline DES & 132.095 .763 & 700.854 .756 & 784.532 .844 & 883.217 .603 & 1.702 .358 .740 \\
\hline & 1.001 .709 .310 & 6.457 .125 .007 & 7.629 .686 .142 & 9.067 .702 .603 & 12.294 .235 .046 \\
\hline & & 5.455 .415 .697 & 1.172 .561 .135 & 1.438 .016 .461 & 3.226 .532 .443 \\
\hline
\end{tabular}

Sumber: PT Gunung Sakti Makmur (2016)

Dari penjualan jasa (coal stockpile, coal screening dan coal blending) tahun 2012 yaitu sebesar Rp 1.001.709.310 yang dibandingkan dengan penjualan jasa (coal stockpile, coal screening dan coal blending) tahun 2013 yaitu sebesar Rp 6.457.127.020 terdapat selisih penjualan jasa (coal stockpile, 
coal screening dan coal blending) yaitu sebesar Rp 5.455.415.697. Karena selisihnya penjualan dengan tahun yang lain tinggi menimbulkan kecurigaan atas transaksi yang terkait pada tahun 2012. Setelah dilakukan penelitian dan penelaahan lebih lanjut, ternyata ada penjualan jasa (coal stockpile, coal screening dan coal blending) yang tidak diakui pada saat terjadinya transaksi atau disebut cash basis. Penjualan jasa (coal stockpile, coal screening dan coal blending) yang terjadi pada tahun 2012 baru diakui pada tahun 2013.

Dari analisis penulis, kondisi pertama memenuhi kriteria karena perusahaan mengetahui seberapa besar penghasilan yang diperoleh dari masing-masing kegiatan usaha (coal stockpile, coal screening dan coal blending), dimana setiap pendapatannya dapat diukur dengan dilihat dari jumlah tonase batubara yang masuk maupun keluar dengan asumsi tarif setiap layanan jasa yang diberikan sudah ditentukan oleh perusahaan dan diakui setiap transaksinya. Dari kondisi kedua bisa dilihat sisi manfaat ekonomi yang diperoleh perusahaan dari pendapatan kegiatan usaha (coal stockpile, coal screening dan coal blending). Adapun kriteria yang digunakan PT Gunung Sakti Makmur di dasarkan pada hal-hal berikut:

a. Hasil penjualan jasa yang menjadi pendapatan memiliki harga satuan rupiah dan dapat diukur oleh perusahaan.

b. Hasil penjualan tersebut akan mendapatkan aliran masuk berupa aktiva lancar bagi perusahaan.

Berdasarkan Standar Akuntansi Keuangan nomor 23, bahwa suatu perusahaan dapat membuat estimasi yang handal terhadap pendapatan yang akan diterima setelah perusahaan mencapai persetujuan dengan pihak lain dalam hal berikut:

a. Hak masing-masing pihak yang pelaksanaannya dapat dipaksakan dengan kekuatan hukum berkenaan dengan jasa yang diberikan dan diterima pihak-pihak tersebut.

b. Imbalan yang harus dipertukarkan.

c. Cara dan persyaratan pembayaran serta penyelesaian.

Kondisi-kondisi di atas telah memberikan gambaran yang telah diidentifikasi dari sebuah transaksi atas jasa coal stockpile, coal screening dan coal blending yang telah disesuaikan dengan standar akuntansi keuangan, karena selama ini perusahaan mengakui pendapatan berdasarkan satuan rupiah. Maka transaksi yang berlaku dalam mata uang asing akan disesuaikan dengan kurs standar yang berlaku pada saat terjadinya transaksi, dalam menjalankan operasinya perusahaan tersebut mengukur nilai pendapatan, jika telah ada persetujuan dari customer. Kemudian akan dilaporkan dalam laporan keuangan yaitu laporan laba rugi tahun berjalan.

\section{Simpulan Dan Saran}

\subsection{Simpulan}

Dalam perlakuan akuntansi mengenai pengakuan pendapatan, hal ini dapat dilihat dari beberapa kriteria yang dapat dijabarkan sebagai berikut:

1. PT Gunung Sakti Makmur menggunakan metode accrual basis dalam pengakuan pendapatannya. dan menerapkan pengakuan dan pengukuran pendapatan berdasarkan PSAK No. 23 (Revisi 2015)

3. Adapun dampak yang terkait dari pengakuan dan pengukuran pendapatan yang terjadi adalah penyajian laporan keuangan yang tidak tepat yang mengakibatkan kesalahan dalam pengambilan keputusan baik dari internal perusahaan maupun eksternal perusahaan.

\subsection{Saran}

Dari hasil pembahasan yang telah dilakukan oleh penulis atas penerapan PSAK No. 23 (Revisi 2015) tentang pengakuan pendapatan pada PT Gunung Sakti Makmur, maka penulis mencoba memberikan 
saran-saran atas berbagai hal yang dianggap perlu dalam batas kemampuan penulis, yaitu:

1. Dalam pencatatan piutang, sebaiknya perusahaan menetapkan kebijakan terhadap cadangan kerugian piutang agar perusahaan tidak mengalami kerugian terhadap piutang yang tertagih, serta menetapkan kebijakan penyisihan dari total seluruh tagihan yang akan diterima sebagai pendapatan sampai waktu tagihan tersebut dibayar, agar uang yang tertanam pada pelanggan dapat menghasilkan pendapatan, yaitu pendapatan bunga walaupun jumlahnya relatif kecil.

2. Dalam penyusunan laporan keuangan sebaiknya diperinci lebih detail lagi pendapatan dari masing-masing layanan jasa yang diberikan guna lebih mempermudah para pengguna laporan keuangan lebih ringkas dalam mengambil keputusan.

3. Dalam penelitian lebih dalam mengenai pendapatan selanjutnya diharap agar peneliti menyiapkan data-data perusahaan yang terkait lebih terperinci untuk mempermudah dalam penyelesaian masalah yang sedang diteliti.

4. Dalam penyusunan laporan keuangan laba rugi seharusnya dipisahkan antara beban operasional dan beban non-operasional guna tersusunnya laporan keuangan yang sesuai standar penyusunan laporan keuangan menurut PSAK.

\section{Daftar Pustaka}

Hadi, Sutrisno. 2007. Statistik 2. Andi Offset. Yogyakarta.

Harahap, Sofyan Syafri. 2007. Analisis Kritis atas Laporan Keuangan. PT Raja Grafindo Persada. Jakarta.

Hendriksen, Van Breda. 2002. Teori Akuntansi. Penerbit Interaksa. Batam.

Hermanto. 2005. Analisis Pengaruh Pelatihan, Pendidikan dan Pembinaan Karyawan terhadap Kinerja Pegawai Sekretariat Kabupaten Sorong. Jurnal Aplikasi Manajemen. Vol. 3. No. 2. Hal. 131-139. Sorong.

Pawan, Elisabeth Caroline. 2013. Pengakuan, pengukuran, pengungkapan dan pelaporan Pendapatan berdasarkan PSAK No.23 pada PT Pegadaian. Jurnal EMBA. Vol. 1 No. 3 Juni 2013. Hal. 349356. Manado.

Stice, James D., Stice, Earl K., dan Skousen, K.Fred. 2009. Akuntansi Intermediate. Edisi Keenam Belas. Buku 1. Salemba Empat. Jakarta.

Sugiri, Slamet Sodikin, dan Agus, Riyono Bogat. 2016. Pengantar Akuntansi 1. Edisi kesembilan. UPP STIM YKPN. Yogyakarta.

Sugiyono. 2005. Memahami Penelitian Kualitatif.Alfabeta. Bandung. 2012. Metode Penelitian Kuantitatif Kualitatif dan R\&D. Alfabeta. Bandung.

T.Horngren, Charles dan T.Harrison, Walter. 2007. Akuntansi Jilid Satu. Edisi Tujuh. Erlangga. Jakarta.

Tjiptono, Fandy. 2007. Pemasaran Strategik. Penerbit Andi. Yogyakarta.

Worung, Yefie Ignasia. 2012. Analisis Penerapan PSAK No. 23 Terhadap Pengakuan dan Pengukuran Pendapatan pada PT Telekomunikasi Indonesia Kandatel Manado. Skripsi. Manado. 